\title{
ADSORPSI ION LOGAM TEMBAGA MENGGUNAKAN NANO ZEOLIT ALAM YANG DIAKTIVASI
}

\section{Adsorption of Copper lons Using Activated Nano Natural Zeolite}

\section{Yulianis*, Mahidin, dan Syaifullah Muhammad}

Jurusan Teknik Kimia, Fakultas Teknik, Universitas Syiah Kuala

Jl. Tgk. Syech Abdurrauf No. 7, Banda Aceh, 23111, Indonesia

*e-mail: yulianispratama@gmail.com

Diterima: 6 April 2017, revisi akhir: 15 Juni 2017 dan disetujui untuk diterbitkan: 20 Juni 2017

\begin{abstract}
ABSTRAK
Penelitian ini bertujuan untuk melihat kemampuan zeolit alam yang berasal dari Blang Pidie, Kabupaten Aceh Barat Daya, Provinsi Aceh, Indonesia yang diaplikasikan sebagai adsorben untuk menyerap ion logam berat tembaga $\left(\mathrm{Cu}^{2+}\right)$ dalam larutan. Penelitian dilakukan dengan peningkatan unjuk kerja zeolit alam melalui pengecilan ukuran sampai nano partikel, selanjutnya diaktivasi fisika dan aktivasi kimia menggunakan $\mathrm{HCl} 0,05 \mathrm{M}$ kemudian dikalsinasi pada temperatur $350{ }^{\circ} \mathrm{C}$ selama 2 jam. Uji adsorpsi ion logam $\mathrm{Cu}^{2+}$ terhadap nano zeolit alam setelah aktivasi dilakukan dengan metode batch untuk menentukan pengaruh waktu kontak, berat adsorben, $\mathrm{pH}$, dan konsentrasi awal. Hasil penelitian menunjukkan adsorpsi optimum pada konsentrasi awal $40 \mathrm{mg} / \mathrm{L}$, berat adsorben $1 \mathrm{gram}, \mathrm{pH}$ 6 selama waktu kontak 120 menit dengan persen ion logam $\mathrm{Cu}^{2+}$ yang terserap sebesar $99,86 \%$ dan kapasitas adsorpsi sebesar 7,789 $\mathrm{mg} / \mathrm{g}$. Isotermal adsorpsi menyerupai isoterm Freundlich dengan nilai $\mathrm{R}^{2}$ 0,9685, konstanta Freundlich $\left(K_{f}\right)$ sebesar $111,99 \mathrm{mg} / \mathrm{g}$ dan nilai $\mathrm{n}$ sebesar 0,986 . Studi kinetika menunjukkan bahwa adsorpsi ion logam $\mathrm{Cu}^{2+}$ mengikuti model kinetika orde dua semu dengan nilai regresi linier 0,9997 dan nilai konstanta $0,121 \mathrm{~min}^{-1}$.
\end{abstract}

Kata kunci: Zeolit alam, nano partikel, adsorpsi, tembaga $\left(\mathrm{Cu}^{2+}\right)$, isothermal

\section{ABSTRACT}

This study was aimed to find out the ability of natural zeolite coming from Blang Pidie, South West Aceh District, Aceh Province, Indonesia, which was applied as an adsorbent to adsorp heavy metal copper $\left(\mathrm{Cu}^{2+}\right)$ ions in aqueous solution. This research was conducted to enhance the performance of natural zeolite by downsizing it to nano particles, then activated physically and chemically using $0.05 \mathrm{M} \mathrm{HCl}$, then calcined at temperature $350^{\circ} \mathrm{C}$ for 2 hours. Test of $\mathrm{Cu}^{2+}$ metal ion adsorption to nano natural zeolite after activation was done by batch method to determine the effect of contact time, weight of the adsorbent, $\mathrm{pH}$, and initial concentration. The results showed that the optimum adsorption at the initial concentration $38.998 \mathrm{mg} / \mathrm{L}$, weight adsorbent $1 \mathrm{gram}$, $\mathrm{pH} 6$ during 120 minutes of the contact time with the percentage metal ion $\mathrm{Cu}^{2+}$ adsorption up to $99.86 \%$ and adsorption capacity $7.789 \mathrm{mg} / \mathrm{g}$. Isothermal adsorption ressembled with the isotherms Freundlich with the $R^{2}$ value of 0.9685 , Freundlich constants (Kf) $111.99 \mathrm{mg} / \mathrm{g}$ and $n$ value 0.986 . The kinetic studies indicated that the adsorption of metal ions $\mathrm{Cu}^{2+}$ could be described by pseudo second order kinetic model with linear regression value 0.9997 and a constant value $0.121 \mathrm{~min}^{-1}$.

\section{Keywords: Natural zeolite, nano particle, adsorption, copper $\left(\mathrm{Cu}^{2+}\right)$, isothermal}

\section{PENDAHULUAN}

Tingginya penggunaan logam berat beberapa dekade terakhir ini mengakibatkan meningkatnya kandungan logam berat dalam lingkungan terutama di lingkungan perairan (Erdem et al., 2004). Kontribusi logam berat diantaranya dari air asam tambang akibat dari aktivitas pertambangan mineral logam dan batubara, 
limbah industri dan domestik, pertanian, hujan asam dan lain lain. Logam berat menjadi perhatian khusus karena logam berat tidak dapat didegradasi sehingga mudah terakumulasi dalam lingkungan ( $\mathrm{Fu}$ and Wang, 2011). Tembaga adalah salah satu logam yang banyak terkandung pada limbah industri. Tingginya kandungan logam tembaga dapat berdampak buruk bagi terhambatnya pertumbuhan biota perairan dan mengakibatkan berbagai penyakit bagi manusia (Simate and Ndlovu, 2014).

Teknik yang telah dikembangkan dalam pengolahan limbah terutama dalam penyerapan logam diantaranya adalah presipitasi (Macingova and Luptakova, 2012), ion exchange (Gaikwad et al., 2010), teknologi membran (Al-Zoubi et al., 2010), elektrokimia (Luptakova et al., 2012), elektrodialisa (Buzzi et al., 2011), secara biologi (Kumar et al., 2013), dan adsorpsi (Mohan and Chander, 2006; Motsi et al., 2009). Diantara metode tersebut adsorpsi yang paling diminati karena ekonomis dan mekanisme yang efisien serta bahan bakunya tersedia di alam (Masukume et al., 2014).

Adsorpsi adalah suatu proses dimana suatu komponen bergerak dari suatu fasa menuju permukaan yang lain sehingga terjadi perubahan konsentrasi pada permukaan. Zat yang diserap disebut adsorbat sedangkan zat yang menyerap disebut adsorben (Treybal, 1980). Proses difusi (perpindahan) pada adsorpsi menyebabkan molekul-molekul dari fluida ke permukaan adsorben padat berdasarkan interaksi molekuler antara adsorben dengan adsorbat. Adsorben yang ekonomis dan menarik secara komersial diantaranya adalah mempunyai daya serap yang tinggi, berupa zat padat yang mempunyai luas permukaan yang besar, tidak boleh larut dalam zat yang akan diadsorpsi, tidak boleh mengadakan reaksi kimia dengan campuran yang akan dimurnikan, dapat diregenerasi kembali dengan mudah, tidak meninggalkan residu berupa gas yang berbau, mudah didapat dan harganya murah (Richardson et al., 2002).

Pada penelitian ini akan dilakukan adsorpsi ion logam tembaga dalam larutan menggunakan adsorben dari zeolit alam yang diperoleh dari Blang Pidie Kabupaten Aceh Barat Daya Propinsi Aceh. Alasan pemilihan teknologi adsorpsi menggunakan zeolit alam ini adalah tidak hanya karena ekonomis, tetapi juga dikarenakan tersedianya sumber daya mineral zeolit dalam jumlah yang besar, mudah diperoleh dan belum adanya peneliti yang menggunakan zeolit alam dari daerah tersebut untuk proses pengolahan limbah.

Persiapan zeolit alam sebagai adsorben terlebih dahulu dimodifikasi untuk meningkatkan performance dengan mengecilkan ukurannya sampai ukuran nano partikel, selanjutnya diaktivasi fisika dan kimia serta penyeragaman kation sehingga dapat menyerap ion logam berat tembaga $\left(\mathrm{Cu}^{2+}\right)$. Logam berat yang akan digunakan dari larutan artifisial $\mathrm{CuSO}_{4} \cdot 5 \mathrm{H}_{2} \mathrm{O}$. Peningkatan performance zeolit alam sebagai salah satu perwujudan konservasi sumberdaya mineral yaitu menggunakan metode atau teknologi pengolahan dengan maksud untuk meningkatkan nilai kualitas zeolit alam sehingga logam berat dalam limbah dapat terserap secara maksimal.

Penelitian terdahulu mengenai penyerapan logam berat dalam air asam tambang dengan adsorben zeolit alam pernah dilakukan oleh (Motsi et al., 2009). Dalam penelitian (Motsi et al., 2009) menyatakan bahwa zeolit alam sebagai adsorben tanpa modifikasi kimia dapat menyerap logam $\mathrm{Fe}^{2+}, \mathrm{Cu}^{2+}, \mathrm{Zn}^{2+}$, dan $\mathrm{Mn}^{2+}$ dalam air asam tambang, dilakukan dalam kondisi batch. Proses adsorpsi pada penelitian tersebut dengan variasi pengaruh tingkat $\mathrm{pH}$, massa zeolit, ukuran partikel, dan temperatur. Zeolit alam memberikan hasil yang sangat baik dalam menyerap logam berat $\mathrm{Zn}^{2+}$ sebesar $67,8 \%, \mathrm{Fe}^{2+}$ sebesar $59,9 \%, \mathrm{Cu}^{2+}$ sebesar $56,8 \%$, dan $\mathrm{Mn}^{2+}$ sebesar $18,9 \%$ pada air asam tambang. Peningkatan performance zeolit alam sangat disarankan untuk optimalisasi penyerapan.

Dalam meningkatkan performance zeolit selain dengan modifikasi, penelitian juga dikembangkan ke arah pengecilan ukuran zeolit hingga menjadi nano partikel. Menurut Mintova dalam (Muhammad et al., 2014) nano zeolit adalah alumina silikat berpori kristal dengan dimensi molekul 
antara 10-1000 nm dari ukuran partikel. Merubah ukuran zeolit alam menjadi nano zeolit dilakukan dengan cara penghancuran menggunakan ball mill. Nano zeolit memiliki luas permukaan yang lebih besar dan mengurangi jalur difusi panjang karena ukuran partikel yang lebih kecil. Pengecilan ukuran partikel dengan skala nanometer mengarah kepada sifat zeolit yang menjadikan zeolit sebagai bahan adsorben yang sangat menjanjikan untuk berbagai aplikasi (Muhammad et al., 2014).

Dalam penelitiannya (Noroozifar et al., 2014) menggabungkan antara modifikasi kimia dan zeolit nano partikel yaitu modifikasi nano zeolit dengan baloform untuk menghilangkan arsenat dari air limbah. Hasil proses adsorpsi menunjukkan bahwa arsenat dapat diserap hingga lebih dari 99\%. Dari sudut pandang komersial cara ini dianggap ekonomis karena ketersediaan zeolit alam yang melimpah dan proses yang sederhana (Noroozifar et al., 2014).

\section{METODOLOGI PENELITIAN}

Alat yang digunakan adalah jaw crusher, ball mill, sieve shaker, alpine residue, magnetic stirrer $(30 \mathrm{~mm})$, motor pengaduk, oven dryer (Memmeth DIN 12880-KI), pH meter (Hanna Instruments), stirrer plate (Barnstead Thermolyne Cimarec), pipet tetes, kertas saring (Whatmann-41), corong penyaring, timbangan analitik (Shimadzu AW-220), screening (ayakan), stopwatch, pipet ukur $25 \mathrm{ml}$, gelas ukur $100 \mathrm{ml}$, erlenmeyer 250 $\mathrm{ml}$, dan botol aquades. Bahan yang digunakan adalah zeolit alam dari Kabupaten Aceh Barat Daya, Provinsi Aceh, limbah artifisial $\mathrm{CuSO}_{4} .5 \mathrm{H}_{2} \mathrm{O}$, aquades, $\mathrm{HCl}, \mathrm{NaOH}$ dan $\mathrm{H}_{2} \mathrm{SO}_{4}$.

\section{Persiapan Aktivasi Nano Zeolit Alam}

Zeolit dibersihkan dan dikeringkan selanjutnya dilakukan proses pengecilan ukuran partikel dengan menggunakan jaw crusher dan ball mill. Keluaran dari ball mill diayak dengan sieve shaker sehingga diperoleh residu butiran zeolit berukuran nano partikel. untuk menghilangkan pengotor nano zeolit dicuci menggunakan aquades selama 1 jam pada suhu $70^{\circ} \mathrm{C}$ lalu diendapkan. Endapan yang terbentuk kemudian dikeringkan pada suhu $105^{\circ} \mathrm{C}$. Selanjutnya diaktivasi dengan asam $\mathrm{HCl}$ $0,05 \mathrm{M}$ dengan perbandingan berat zeolit : asam yaitu $1: 3$ dan campuran diaduk selama 1 jam pada suhu $70^{\circ} \mathrm{C}$ lalu diendapkan. Endapan yang terbentuk kemudian dikeringkan menggunakan oven pada suhu $105^{\circ} \mathrm{C}$. Selanjutnya zeolit dicuci dengan aquades selama 1 jam pada suhu $70^{\circ} \mathrm{C}$, kemudian diendapkan selama 24 jam dan dikeringkan pada suhu $105^{\circ} \mathrm{C}$. Kemudian dikalsinasi selama 2 jam di dalam furnace pada temperatur $350^{\circ} \mathrm{C}$.

\section{Proses Adsorpsi lon Logam $\mathrm{Cu}^{2+}$}

Nano zeolit alam yang telah diaktivasi dengan berat bervariasi 0,$25 ; 0,5 ; 1$; dan 2 gram dimasukkan ke limbah artifisial logam berat $\mathrm{CuSO}_{4} .5 \mathrm{H}_{2} \mathrm{O}$ dengan konsentrasi yang bervariasi yaitu 10, 20, 40, 80, 100 ppm sebanyak masing-masing $200 \mathrm{ml}$ beaker glass. Untuk mengatur $\mathrm{pH}$ larutan digunakan $\mathrm{NaOH} 1 \mathrm{M}$ dan $\mathrm{H}_{2} \mathrm{SO}_{4} 1 \mathrm{M}$. Kemudian diaduk dengan kecepatan 110 rpm selama waktu kontak masing-masing $30,60,90,120,180$ menit pada temperatur ruang. Konsentrasi $\mathrm{Cu}^{2+}$ dalam larutan diukur menggunakan alat Atomic Adsorption Spectrophotometer (AAS).

\section{Karakterisasi Zeolit}

Karakterisasi zeolit dilakukan menggunakan $X$-Ray Difraction (XRD), Fourier Transform Infrared (FTIR), dan Scanning Electron Microscopy (SEM).

\section{Analisa Data Adsorpsi Kapasitas adsorpsi}

Perhitungan kapasitas adsorpsi zeolit pada keadaan kesetimbangan dihitung dengan persamaan (1).

$$
q e=\frac{\left(C_{0}-C_{e}\right) V}{m}
$$

\section{Isotermal adsorpsi}

Model persamaan isotermal Langmuir menggunakan persamaan (2). 


$$
\frac{1}{\mathrm{q}_{\mathrm{e}}}=\frac{1}{\mathrm{ab}} \frac{1}{\mathrm{Ce}}+\frac{1}{\mathrm{~b}}
$$

Model persamaan isotermal Freundlich menggunakan persamaan (3).

$$
\log q_{e}=\log \mathrm{K}+\frac{1}{\mathrm{n}} \log C_{e}
$$

\section{Kinetika adsorpsi}

Kinetika adsorpsi logam $\mathrm{Cu}^{2+}$ ditentukan menggunakan persamaan (4) orde satu semu dan persamaan (5) orde dua semu.

$$
\begin{aligned}
& \log \left(q_{e}-q_{t}\right)=\log q_{e}-\frac{k_{1} t}{2,303} \\
& \frac{\mathrm{t}}{\mathrm{q}_{\mathrm{t}}}=\frac{1}{\mathrm{k}_{2} \mathrm{q}_{\mathrm{e}}}+\frac{1}{\mathrm{q}_{\mathrm{e}}} \mathrm{t}
\end{aligned}
$$

\section{HASIL DAN PEMBAHASAN Karakterisasi XRD, FTIR, SEM}

Hasil uji XRD nano zeolit alam aktivasi ditampilkan pada Gambar 1 dan Spektra FTIR nano zeolit alam aktivasi ditampilkan pada Gambar 2.

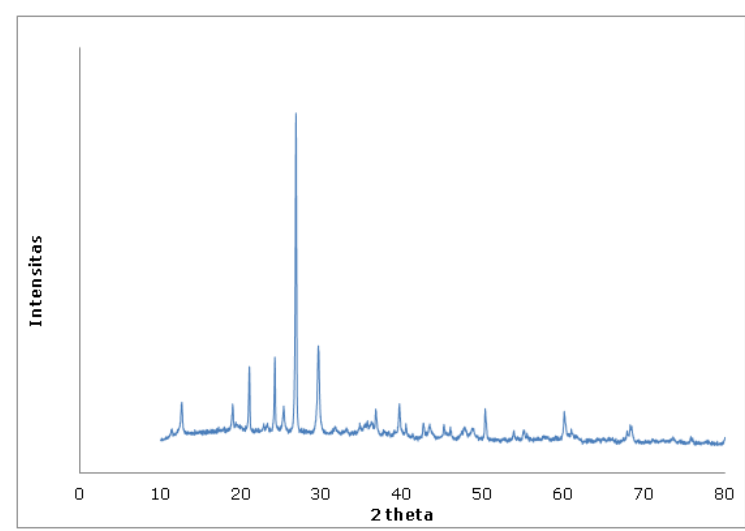

Sumber: Data penelitian sendiri

Gambar 1. Hasil uji XRD nano zeolit alam aktivasi

Hasil Tes XRD (Gambar 1) memperlihatkan bahwa refleksi dengan intensitas yang tajam pada daerah $2 \theta=26,65^{\circ}(\mathrm{d}=$ 3,34 A) adalah karakteristik mineral mineral kuarsa $\left(\mathrm{SiO}_{2}\right)$, dan refleksi dengan intensitas terbesar $2 \theta=29,43^{\circ}(d=3,03 \mathrm{~A})$ mineral kalsit $\left(\mathrm{CaCO}_{3}\right)$, serta mineral klinoklor $\left[(\mathrm{Mg}, \mathrm{Fe})_{6}(\mathrm{Si}, \mathrm{Al}) \quad 4 \mathrm{O}_{10}(\mathrm{OH})_{8}\right]$ memberikan refleksi dengan intensitas terbesar $2 \theta=18,76^{\circ}(d=4,7 \mathrm{~A})$.

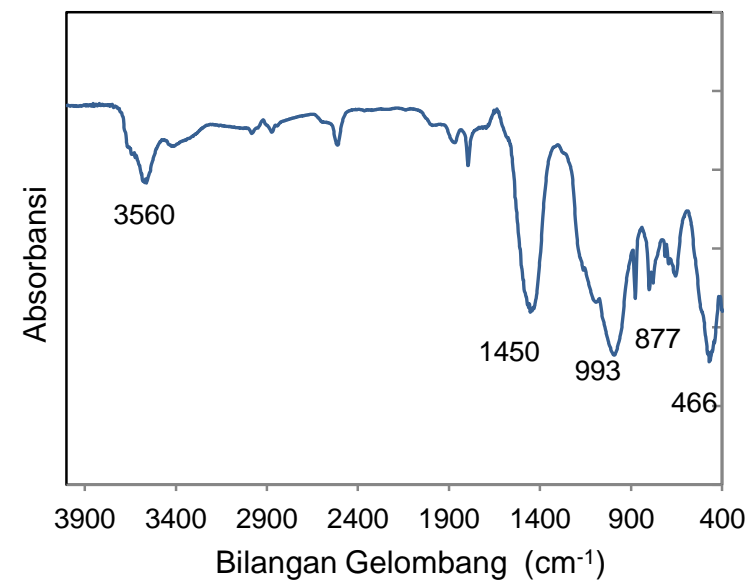

Sumber: Data penelitian sendiri

Gambar 2. Spektra FTIR nano zeolit alam aktivasi

Hasil karakterisasi dari FTIR (Gambar 2) memperlihatkan bahwa gugus fungsi yang terdapat pada sampel yang diteliti menunjukkan karakter kerangka struktur zeolit yaitu terdapat puncak $877-993 \mathrm{~cm}^{-1}$ yang merupakan vibrasi ulur asimetris $\mathrm{Si}-\mathrm{O}$ dan Al-O interpretasi dari serapan ikatan pada unit struktur utama zeolite (Barczyk et al., 2014). Ion karbonat pada nano zeolit alam nano zeolit setelah dilakukan aktivasi yaitu pada puncak $1450 \mathrm{~cm}^{-1}$. Bilangan gelombang karbonat berada pada 1450$1410 \mathrm{~cm}^{-1}$ (Coates et al., 2006).

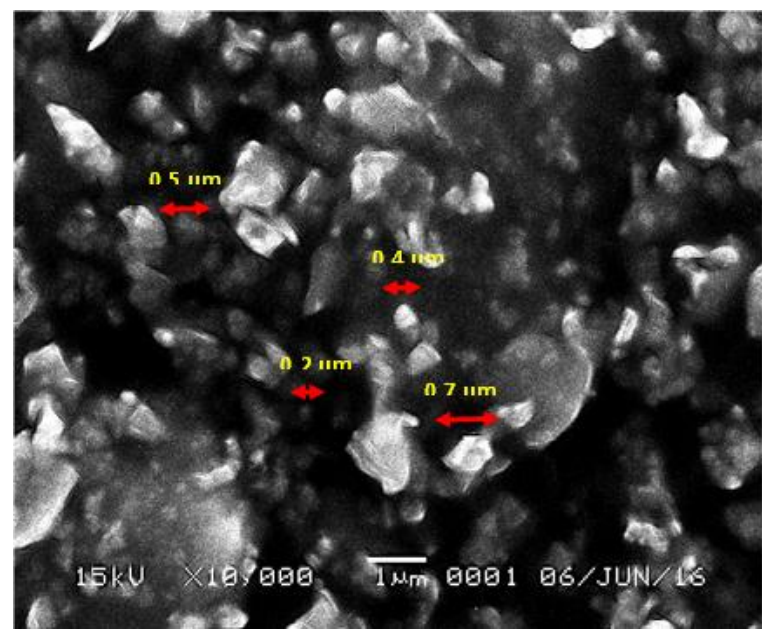

Sumber: Dokumentasi pribadi

Gambar 3. SEM nano zeolit alam aktivasi

Karakterisasi SEM nano zeolit alam aktivasi ditampilkan pada Gambar 3 . Karakterisasi dengan SEM digunakan untuk mengetahui morfologi dari nano zeolit yang telah diaktivasi memperlihatkan 
bahwa zeolit berhasil dikecilkan ukuran sampai nano partikel.

\section{Adsorpsi Logam $\mathrm{Cu}^{2+}$}

Parameter yang mempengaruhi penyerapan ion logam adalah waktu kontak, berat adsorben, $\mathrm{pH}$, konsentrasi awal logam $\mathrm{Cu}^{2+}$.

\section{Pengaruh Waktu Kontak Terhadap Efisiensi Penyerapan Ion Logam $\mathrm{Cu}^{2+}$}

Pengujian ini dilakukan untuk konsentrasi $40 \mathrm{ppm}$. Lamanya waktu kontak antara adsorbat dengan adsorben mempengaruhi efisiensi penyerapan. Semakin lama waktu kontak, maka ion $\mathrm{Cu}^{2+}$ yang terserap akan semakin meningkat, seperti ditampilkan pada Gambar 4. Pada konsentrasi 40 ppm dengan massa 1 gram adsorben nano zeolit alam aktivasi dan kecepatan pengaduk $110 \mathrm{rpm}$, diperoleh efisiensi penyerapan pada saat 30,60, 90, 120 menit berturut-turut adalah 95,99; 97,87 99,09; dan 99,57\%. Berdasarkan data di atas, terlihat bahwa efisiensi penyerapan terbesar adalah 99,57\% pada menit ke-120 yang merupakan waktu kesetimbangan.

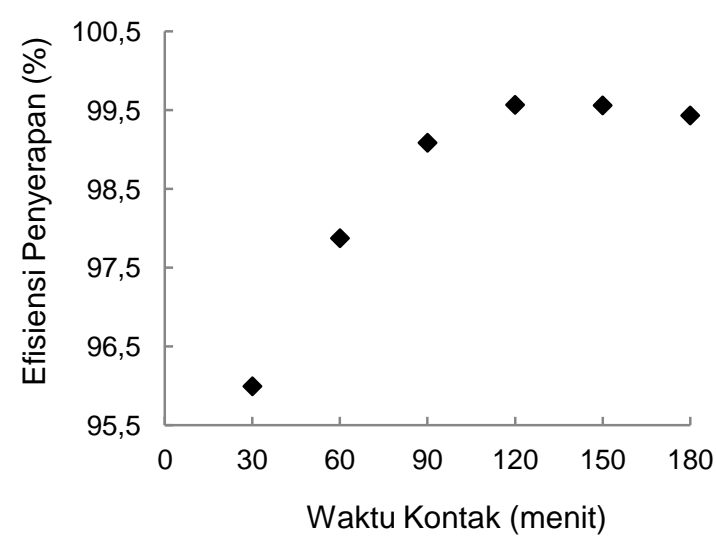

Sumber: Data penelitian sendiri

Gambar 4. Hubungan waktu kontak terhadap efisiensi penyerapan ion logam $\mathrm{Cu}^{2+}$ pada konsentrasi 40 ppm, dengan massa adsorben 1 gram, $\mathrm{pH} 2$

\section{Pengaruh Berat Adsorben Terhadap Efisiensi Penyerapan Ion Logam $\mathrm{Cu}^{2+}$}

Berat adsorben yang digunakan dalam adsorpsi logam $\mathrm{Cu}^{2+}$ adalah 0,$25 ; 0,5 ; 1$; dan 2 gram. Proses adsorpsi dilakukan dengan waktu kontak 120 menit pada pH 2. Pengaruh berat adsorben terhadap efisiensi penyerapan ion logam $\mathrm{Cu}^{2+}$ dapat dilihat pada Gambar 5.

Berdasarkan Gambar 5 dapat dilihat bahwa efisiensi penyerapan dengan berat 0,25 gram hanya sebesar $55,94 \%$, kemudian dengan berat adsorben 0,5 gram efisiensi penyerapan bertambah menjadi $90,13 \%$, pada berat adsorben 1 gram efisiensi penyerapan meningkat hingga $99,57 \%$ dan berat adsorben 2 gram efisiensi penyerapan hanya naik menjadi $99,69 \%$. Dari berbagai variasi berat adsorben tersebut diatas, efisiensi penyerapan optimum dalam menyerap ion logam $\mathrm{Cu}^{2+}$ yaitu pada berat adsorben 1 gram.

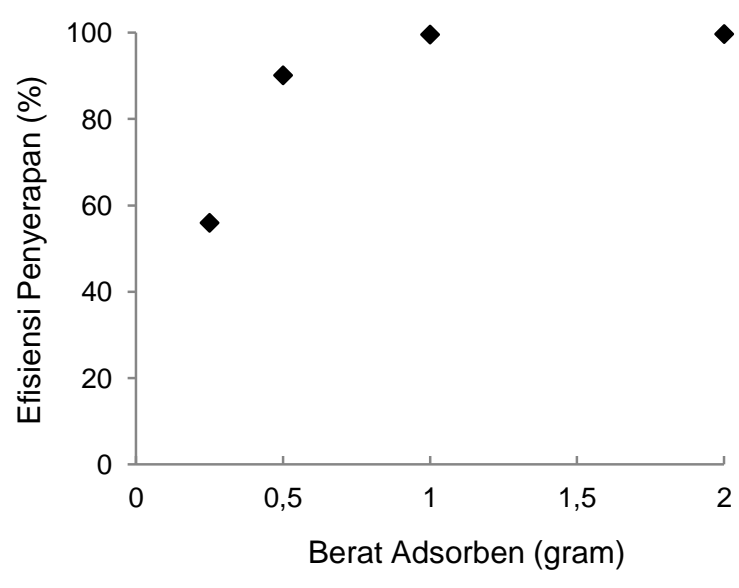

Sumber: Data penelitian sendiri

Gambar 5. Hubungan berat adsorben terhadap efisiensi penyerapan ion logam $\mathrm{Cu}^{2+}$ pada konsentrasi 40 ppm, $\mathrm{pH} 2$ dengan waktu kontak 120 menit

\section{Pengaruh pH Terhadap Efisiensi Penyerapan Ion Logam $\mathrm{Cu}^{2+}$}

$\mathrm{pH}$ yang digunakan dalam adsorpsi logam $\mathrm{Cu}^{2+}$ adalah 2, 4, 6 dan proses adsorpsi dilakukan dengan waktu kontak 120 menit dengan berat 1 gram. Pengaruh $\mathrm{pH}$ terhadap efisiensi penyerapan ion logam $\mathrm{Cu}^{2+}$ dapat dilihat pada Gambar 6 . Semakin bertambah $\mathrm{pH}$ maka efisiensi penyerapan juga semakin bertambah seperti (Gambar 6). Efisiensi penyerapan dengan $\mathrm{pH} 2$ sebesar 99,57\%, kemudian dengan $\mathrm{pH} 4$ efisiensi penyerapan bertambah 99,85\%, dan $\mathrm{pH} 6$ efisiensi 
penyerapan meningkat menjadi $99,86 \%$. Efisiensi penyerapan terbesar adalah pada pH 6.

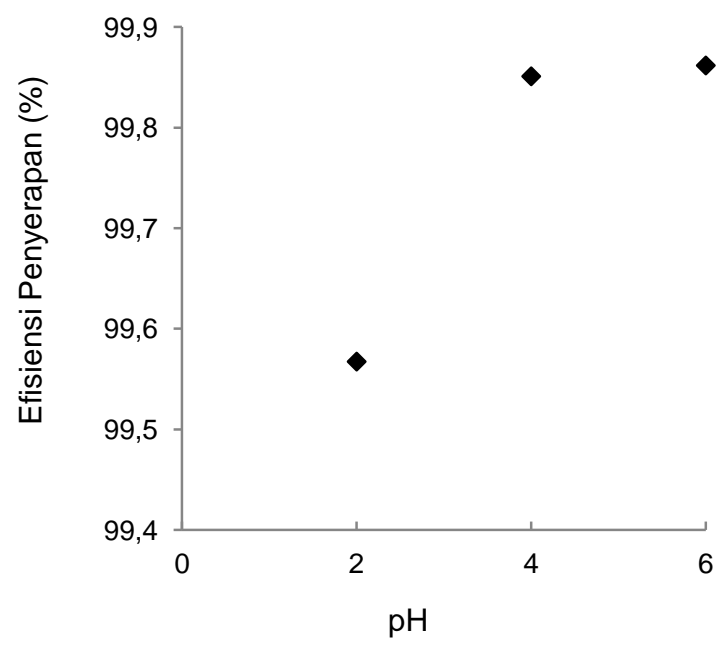

Sumber: Data penelitian sendiri

Gambar 6. Hubungan $\mathrm{pH}$ terhadap efisiensi penyerapan ion logam $\mathrm{Cu}^{2+}$ pada konsentrasi $40 \mathrm{ppm}$, berat adsorben 1 gram, dan waktu kontak 120 menit

\section{Pengaruh Konsentrasi Awal Adsorbat terhadap Efisiensi Penyerapan Ion Logam $\mathrm{Cu}^{2+}$}

Percobaan pengaruh konsentrasi awal adsorbat terhadap kapasitas penyerapan ion logam $\mathrm{Cu}^{2+}$ dilakukan dengan variasi konsentrasi adsorbat yaitu 10; 20; 40; 80; 100 ppm dan proses adsorpsi dilakukan dengan waktu kontak 120 menit, berat adsorben 1 gram, dan kecepatan pengaduk $110 \mathrm{rpm}$. Untuk menentukan pengaruh konsentrasi awal adsorbat terhadap efisiensi penyerapan, maka diplot grafik hubungan antara konsentrasi awal adsorbat dengan efisiensi penyerapan seperti pada Gambar 7.

Berdasarkan Gambar 7 dapat dilihat bahwa terjadi peningkatan efisiensi ppm berturut-turut 99,78\%; 99,81\%; 99,86\%, penyerapan pada konsentrasi 10;20; 40 kemudian terjadi penurunan efisiensi penyerapan pada konsentrasi 80; 100 ppm yaitu 99,80\%; 99,81\%. Terjadi peningkatan pada konsentrasi 40 ppm yang merupakan konsentrasi optimum dengan persentase penyisihan tertinggi sebesar 97,86\%. Penyisihan adsorbat akan cepat pada interval awal dan akhirnya akan mencapai keadaan konstan untuk waktu yang lebih lama seperti terlihat pada data.

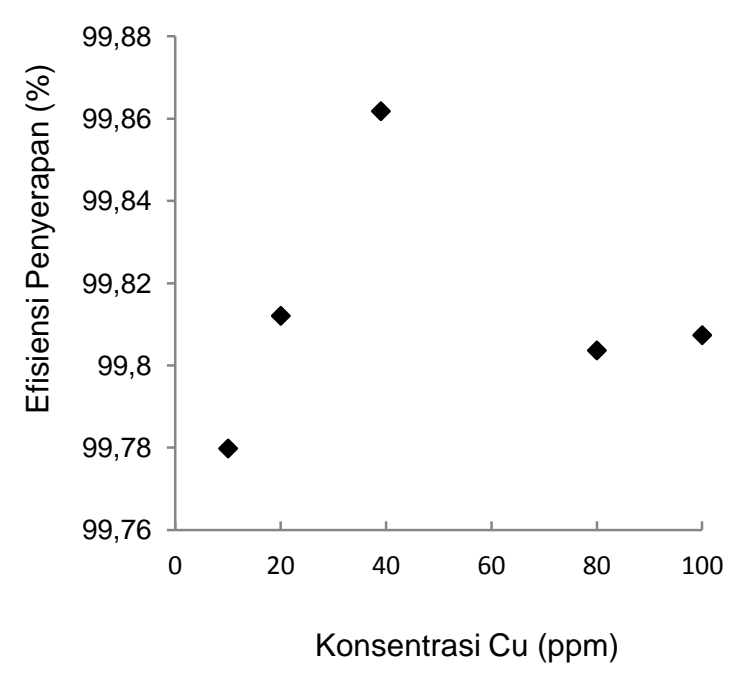

Sumber: Data penelitian sendiri

Gambar 7. Hubungan konsentrasi awal adsorbat (Co) terhadap efisiensi penyerapan ion logam $\mathrm{Cu}^{2+}$ dengan berat adsorben 1 gram, $\mathrm{pH} 6$ dan waktu kontak 120 menit.

\section{Isoterm Adsorpsi}

Isoterm Langmuir adsorpsi ion logam $\mathrm{Cu}^{2+}$ pada setiap konsentrasi 10; 20; 40; 80; 100 ppm, berat adsorben 1 gram dan pH 6 ditampilkan pada Gambar 8. Dan isotherm Freundlich ditampilkan pada gambar 9 .

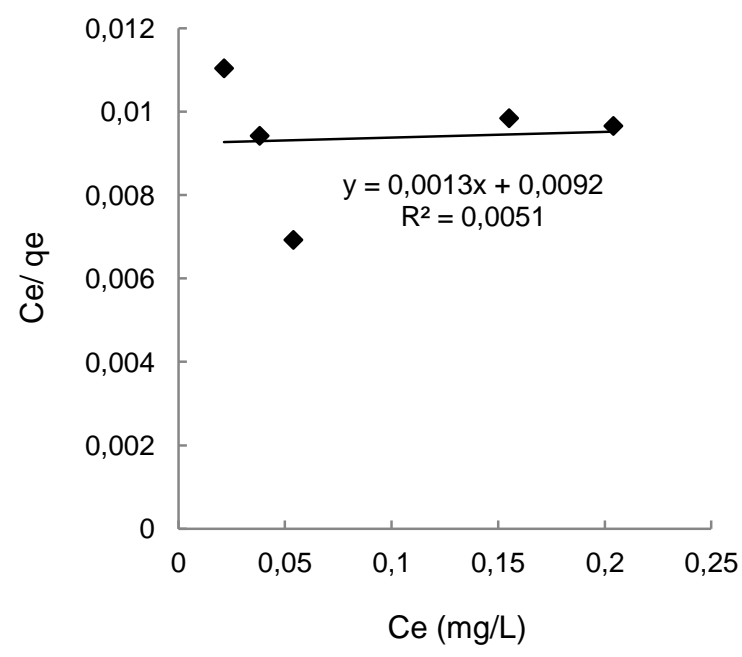

Sumber: Data penelitian sendiri

Gambar 8. Isoterm Langmuir adsorpsi ion logam $\mathrm{Cu}^{2+}$ pada konsentrasi $10 ; 20 ; 40 ; 80 ; 100$ ppm, berat adsorben 1 gram, dan $\mathrm{pH} 6$ 


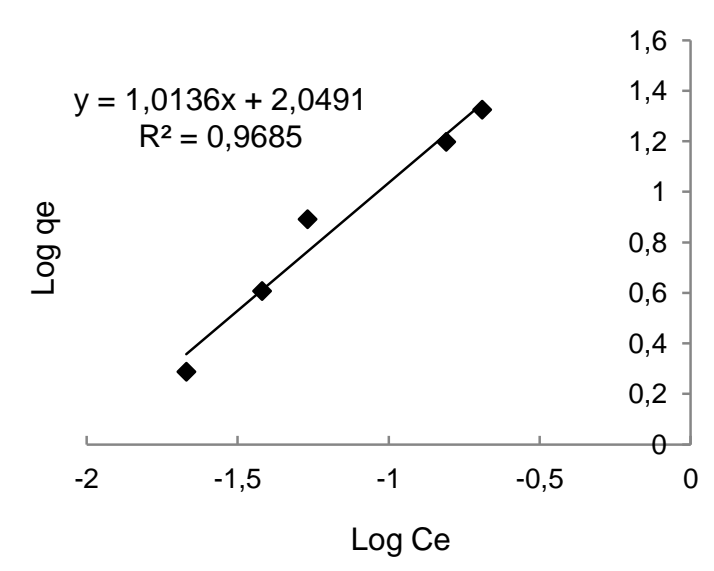

Sumber: Data penelitian sendiri

Gambar 9. Isoterm Freundlich pada pada setiap konsentrasi $10 ; 20 ; 40$; 80; 100 ppm, berat adsorben 1 gram, dan $\mathrm{pH} 6$
Isoterm adsorpsi bertujuan untuk mengetahui kapasitas adsorpsi dari adsorben. Hal ini penting untuk mengetahui apakah adsorben memiliki nilai ekonomis dan komersial sebagai bahan penyerap. Berdasarkan perhitungan model matematika Langmuir dan Freundlich persamaan (2) dan (3) sesuai dengan Gambar 8 dan 9 menjelaskan bahwa Isoterm adsorpsi ion logam $\mathrm{Cu}^{2+}$ menggunakan adsorben nano zeolit alam mengikuti isotherm Freundlich. Nilai konstanta pada masing-masing model isoterm adsorpsi dapat dilihat pada Tabel 2.

Tabel 2. Konstanta Langmuir dan Freundlich untuk adsorpsi ion logam $\mathrm{Cu}^{2+}$

\begin{tabular}{ccccccc}
\hline \multirow{2}{*}{ Ion logam } & \multicolumn{3}{c}{ Langmuir } & \multicolumn{3}{c}{ Freundlich } \\
\cline { 2 - 7 } & $\begin{array}{c}\mathrm{qm} \\
\mathrm{Mg} / \mathrm{g}\end{array}$ & $\mathrm{K}$ & $\mathrm{R}^{2}$ & $N$ & $K_{f}$ & $\mathrm{R}^{2}$ \\
& 769,23 & 0,141 & 0,0051 & 0,98 & 111,9 & 0,968 \\
\hline $\mathrm{Cu}^{2+}$ & & & & & & \\
\hline
\end{tabular}

\section{Kinetika Adsorpsi}

Studi kinetika dilakukan untuk menyediakan informasi mengenai proses dinamika yaitu laju adsorpsi, waktu tinggal dan perpindahan massa seperti koefesien perpindahan massa eksternal dan difusi antar partikel (Motsi et al., 2009). Parameter ini penting saat akan mendisain dan mengoperasionalkan proses adsorpsi dalam pengolahan limbah pada skala industri (Noroozifar et al., 2014). Persamaan kinetika orde satu semu ini ditunjukkan pada Gambar 10. Berdasarkan Gambar 10 diperoleh nilai $\mathrm{R}^{2}$ sebesar 0,6915 , nilai $\mathrm{k}_{1}$ untuk kinetika adsorpsi pada konsentrasi 40 ppm adalah sebesar $0,076 \mathrm{~min}^{-1}$, dan nilai qe sebesar 1,105 $\mathrm{mg} / \mathrm{g}$.

Persamaan orde dua semu ditunjukkan pada Gambar 11. Berdasarkan Gambar 11 diperoleh nilai $\mathrm{R}^{2}$ pada grafik sebesar 0,9997, $\mathrm{k}_{2}$ untuk kinetika adsorpsi pada konsentrasi optimum 40 ppm adalah sebesar $0,121 \mathrm{~min}^{-1}$ dan nilai $q_{\mathrm{e}}$ sebesar $7,868 \mathrm{mg} / \mathrm{g}$.

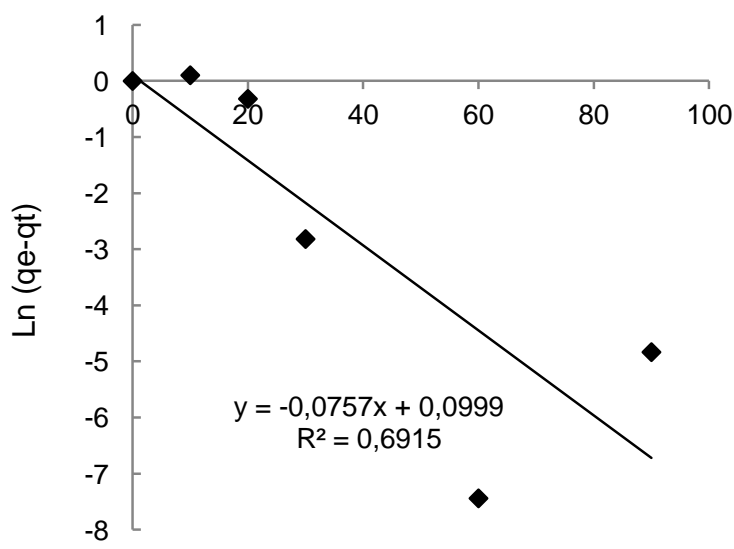

Waktu (menit)

Gambar 10. Kinetika adsorpsi orde satu semu diperoleh nilai $R^{2}$ sebesar 0,6915

Persamaan kinetika adsorpsi yang sesuai untuk adsorpsi logam $\mathrm{Cu}^{2+}$ dengan nano zeolit alam setelah aktivasi mengikuti persamaan orde dua semu, ini dapat dilihat dari nilai $R^{2}$ yang mendekati 1 . 


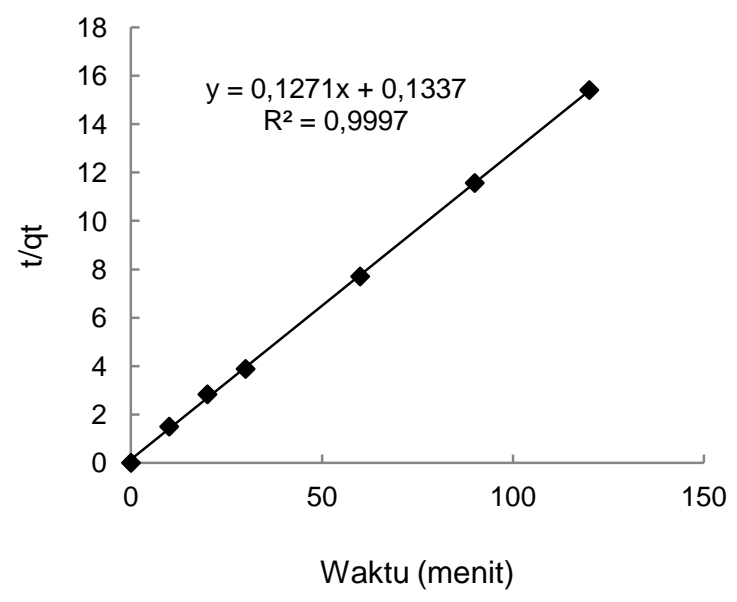

Gambar 11. Kinetika adsorpsi orde dua semu hubungan waktu terhadap t/qt.

\section{KESIMPULAN}

Berdasarkan penelitian yang telah dilakukan dapat disimpulkan bahwa zeolit alam yang berasal dari Blang Pidie Kabupaten Aceh Barat Daya dapat digunakan sebagai alternatif yang menguntungkan untuk proses pengolahan limbah. Mineral pengotor yang terdapat dalam zeolit dapat diminimalisir dengan dilakukan proses aktivasi dan mengecilkan ukurannya sehingga menghasilkan zeolit yang lebih berkualitas.

Nano zeolit alam setelah diaktivasi dapat diaplikasikan sebagai adsorben untuk menyerap ion logam $\mathrm{Cu}^{2+}$ dengan efisiensi penyerapan mencapai 99,86\% dan kapasitas penyerapan sebesar 7,789 $\mathrm{mg} / \mathrm{g}$ pada konsentrasi optimum $40 \mathrm{mg} / \mathrm{L}$, berat adsorben 1 gram, $\mathrm{pH} 6$ selama waktu kontak 120 menit. Proses adsorpsi ion logam $\mathrm{Cu}^{2+}$ menggunakan nano zeolit alam setelah aktivasi menyerupai isotherm Freundlich dengan nilai $\mathrm{R}^{2}$ sebesar 0,9685.

Kinetika adsorpsi penyerapan ion logam $\mathrm{Cu}^{2+}$ menggunakan adsorben nano zeolit alam setelah diaktivasi mengikuti persamaan orde dua semu dengan nilai $R^{2}$ sebesar 0,9997 dan nilai $k_{2}$ sebesar 0,121 $\min ^{-1}$.

\section{UCAPAN TERIMA KASIH}

Penulis menyampaikan terima kasih kepada pembimbing yang telah member- kan arahan dan bimbingan saat melakukan penelitian dan penulisan.

\section{DAFTAR PUSTAKA}

Al-Zoubi, H., Rieger, A., Steinberger, P., Pelz, W., Haseneder, R., H?rtel, G., 2010. Optimization study for treatment of acid mine drainage using membrane technology. Sep. Sci. Technol. 45, 2004-2016. doi:10.1080/01496395.2010.480963

Barczyk, K., Mozgawa, W., Kr?ı, M., 2014. Studies of anions sorption on natural zeolites. Spectrochim. Acta Part A Mol. Biomol. Spectrosc. 133, 876882. doi:10.1016/j.saa.2014.06.065

Buzzi, D.C., Lucas Stéphano Viegas, Flávia P. C. Silvas, Espinosa, D.C.R., Rodrigues, M.A.S., Bernardes, A.M., Tenório, J.A.S., 2011. The use of microfiltration and electrodialysis for treatment of acid mine drainage, in: 11th International Mine Water Association Congress - Mine Water Managing the Challenges. Aachen, Germany., pp. $287-291$.

Coates, J., Coates, John, 2006. Interpretation of Infrared Spectra, A Practical Approach, in: Encyclopedia of Analytical Chemistry. John Wiley \& Sons, Ltd, Chichester, UK. doi:10.1002/9780470027318.a5606

Erdem, E., Karapinar, N., Donat, R., 2004. The removal of heavy metal cations by natural zeolites. J. Colloid Interface Sci. 280, 309-314. doi:10.1016/j.jcis. 2004.08.028

Fu, F., Wang, Q., 2011. Removal of heavy metal ions from wastewaters: A review. J. Environ. Manage. 92, 407418. doi:10.1016/j.jenvman.2010.11. 011

Gaikwad, W.R., Sapkal, V.S., Sapkal, R.S., 2010. Ion exchange system design for removal of heavy metals from acid mine drainage wastewater. Acta Montan. Slovaca Ročník 15, 298-304.

Kumar, R.N., McCullough, C.D., Lund, M.A., 2013. Upper and lower concentration thresholds for bulk 
organic substrates in bioremediation of acid mine drainage. Mine Water Environ. 32, 285-292. doi:10.1007/ s10230-013-0242-8

Luptakova, A., Ubaldini, S., Macingova, E., Fornari, P., Giuliano, V., 2012. Application of physical chemical and biological chemical methods for heavy metals removal from acid mine drainage. Process Biochem. 47, 1633-1639. doi:10.1016/j.procbio. 2012.02.025

Macingova, E., Luptakova, A., 2012. Recovery of metals from acid mine drainage. Chem. Eng. Trans. 28, 109114.

Masukume, M., Onyango, M.S., Maree, J.P., 2014. Sea shell derived adsorbent and its potential for treating acid mine drainage. Int. J. Miner. Process. 133, 52-59. doi:10.1016/j. minpro.2014.09.005

Mohan, D., Chander, S., 2006. Removal and recovery of metal ions from acid mine drainage using lignite?A low cost sorbent. J. Hazard. Mater. 137, 15451553. doi:10.1016/j.jhazmat.2006.04. 053

Motsi, T., Rowson, N.A., Simmons, M.J.H., 2009. Adsorption of heavy metals from acid mine drainage by natural zeolite. Int. J. Miner. Process. 92, 4248. doi:10.1016/j.minpro.2009.02.005
Muhammad, S., Machdar, I., Saputra, E., 2014. Hydrothermal Synthesis of Nanocrystalline Zeolite using Clear Solution, in: The 5th Sriwijaya International Seminar on Energy and Environmental Science \& Technology. pp. 80-86.

Noroozifar, M., Khorasani-Motlagh, M., Naderpour, H., 2014. Modified nanocrystalline natural zeolite for adsorption of arsenate from wastewater: Isotherm and kinetic studies. Microporous Mesoporous Mater. 197, 101-108. doi:10.1016/j. micromeso.2014.05.037

Richardson, J., JH Harker, JR Backhurst, 2002. Chemical engineering. Particle technology and separation processes, 5th ed, Butterworth-Heinemann,. Oxford.

Simate, G.S., Ndlovu, S., 2014. Acid mine drainage: Challenges and opportunities. J. Environ. Chem. Eng. 2 , 1785-1803. doi:10.1016/j.jece. 2014.07.021

Treybal, R.E., 1980. Mass-transfer operations, 3th ed. McGraw-Hill, Singapore. 